\title{
Meaning, What is It
}

\section{Jesus Martinez del Castillo}

Department of Philology, Faculty of Business Studies and Tourism, Universidad de Almería, Almería, Spain

Email address:

jesus.gerardo@ual.es, apofansis@msn.com

\section{To cite this article:}

Jesus Martinez del Castillo. Meaning, What is It. International Journal of Language and Linguistics. Special Issue: Linguistics of Saying. Vol. 3, No. 6-1, 2015, pp. 67-76. doi: 10.11648/j.ijll.s.2015030601.19

\begin{abstract}
Meaning as the original function of language is the arrangement of internal things on the part of the creative and historical individual subject who speaks a particular language. Meaning constitutes the series of contents making up the linguistic world human subjects can manage real things with. Real things are not described with meanings but merely represented and designated. Meanings represent the essence of things thus making them members of a category. In this sense, meaning is the base to create things in as much as they constitute entities. Only through the operation of determination can meanings designate individual real things. Since meaningful categories are intended to particular purposes, meaning is intentional and inclusive.
\end{abstract}

Keywords: Arrangement of Things, Designation, Determination, Real Things, Intentional Meaning, Linguistic Categories

\section{Introduction}

So far in one of the previous articles 1 we studied the role of meaning in language. We analysed

1. The use of language as an instrument for specific purposes and concluded about the precedence of language and thus meaning over the instrumental use of language. Language and meaning are thus autonomous.

2. The linguistic expression in speech. We concluded that a linguistic expression could either mean or connote. Only meaning is structured.

3. Speech acts, and saw that speech acts represent the act of creation of language by individuals, since speech acts are the execution of an intuition on the part of the speaker2. It is in speech acts that you can start with the analysis of meaning. But meaning by definition does not belong to speech but to the particular language, since it is common and inter-individual.

4. Language as a technique in the activity of speaking. Language represents a set of traditional techniques in accordance with the meanings of a language are to be defined. In this sense, we studied language as the activity of speaking, not uniform by varied.

1 Jesus Martinez del Castillo. Meaning and Language. International Journal of Language and Linguistics. Special Issue: Linguistics of Saying. Vol. 3, No. 6-1, 2015, pp. 50-58.

2 Cf. Coseriu 1985a, p. 75; Coseriu, 1986a, pp. 27-32.
5. The configuration of the activity of speaking. We concluded about the importance of the functional language and the structure in it. In order to study any element in language it is necessary to determine the different levels it involves in terms of the structure of the language.

6. The configuration of linguistic content. Linguistic content is structured as well in three levels, designation, meaning and sense.

In other words: we studied the basic tenets to be born in mind when dealing with meaning. And now it is the moment to ask for meaning in it. So then, what is meaning?

\section{Defining Characteristics of Meaning}

In order to define meaning and bearing in mind that meaning is the internal function of language 3 , three important defining aspects of language must be born in mind:

1. Language has meaning: you would rather say that language is meaning;

2. Language is intentional, that is, you can either speak or keep silent, speak in this or that way, in accordance with your purpose and intention.

3 Cf. Coseriu 1985a, p. 46; Cf. Martínez del Castillo, 2015. 
3. Language always manifests itself as a language, that is, in the forms of historical traditions in the techniques of speaking. In this sense language divides humankind in different historical communities, just determined as linguistic communities or speech communities (=languages) 4 .

These three aspects of language must be analysed separately.

\subsection{Language is Meaning, the Conscience of Speakers}

The problem of the definition of meaning is to be analysed in linguistic expressions. It is usually said that language is expression. But expression when applied to language cannot be understood as the simple, immediate and naturally necessary manifestation of language. The expression of language is the expression of objectified meaning. Immediate expressions, purely exclamatory reactions, can have sense, but never can they bear meaning. They are to be interpreted in the context they are the sign of.

For example, you can infer the presence of someone producing a noise out of the very noise. You can infer that there is somebody in the room upstairs if you hear a noise similar to the one people make when they step around. But such a noise, if considered an expression, cannot be considered language, just because it has no objectified meaning. That noise merely conveys the presence of someone making a noise, not the function played by someone in the act of making such a noise. The interpretation of such a fact consists in the inference from the proved existence of the noise to the verification of the presence of somebody, given in the particular real context of that noise. That is, you deduce the presence of somebody based on the real existence of the noise, although you have not verified the connection of both factors (the noise and somebody being upstairs).

On the contrary, the interpretation of linguistic expressions consists in the inference from a proved existence of an expression (the one in its concrete elements) to an essentially different domain, the conscience of speakers. In principle, speakers in themselves have little to do with that concrete expression. The verification is referred to the conscience of the speaker. The connection between the conscience of speakers and linguistic expressions, that is, signs and knowledge, is usually said to be arbitrary. But arbitrary here is to be interpreted as end-directed and historically motivated5.

Hence the fact that materially identical expressions (or very similar expressions) can convey quite different meanings depending on the language (=the system of signification) in accordance with they are to be interpreted. And even within a language the material similarity of expressions does not relate

\footnotetext{
4 Coseriu 1985a, pp. 36 and ff.

5 The concept of arbitrariness by Saussure must be revised in terms of the historically determined condition of linguistic signs. Arbitrary means not necessary but motivated only because of language use, that is, because of the intentional purpose to mean something historically determined (cf. Coseriu 1988, p. 24, footnote 38; Coseriu 1985a, pp. 37-38).
}

to the similarity of meanings. For example, the material similarity of such words as

$$
\text { pair - pear }
$$

does not guarantee the similarity of meanings. In the same way

$$
\text { peace - piece, }
$$

or in a bit different way

$$
\text { sniff, snuff, snub, snug. }
$$

On the contrary, house and home; dog and hound; young and new, denote similar contents but they are materially different.

On the other hand, a particular linguistic expression can have different interpretations. The following example, taken from the written press, at the time,

\section{President Bush swore in his cabinet}

can have two interpretations: "President Bush made the members of his cabinet solemnly promise to fulfil and accept the duties inherent to their jobs"; and "President Bush uttered blasphemous words before the members of his cabinet".

In either case there is no direct connection between the elements used in the expression and the interpretation of them. The only relationship to be found between them is in the conscience of speakers, namely, the creative knowledge of speakers and, in a greater or lesser degree, the command (knowledge) of the technique used in the expression. In comparison with the interpretation made on the noise coming from the room upstairs, the difference consists in the base of the inference. The connection between the noise produced and the agent producing it, constitutes the base of the inference; in the case of linguistic expressions and the content in them, the base for the inference is not direct but in the conscience of speakers. For the interpretation of linguistic expressions it is necessary to start with the elements in the expression and refer them to the conscience of speakers.

The fact that similar expressions do not involve similar meanings and, vice versa, that similar meanings are not expressed with similar means of expression, represents the radical separation of the world of meanings from the world of signs and symptoms6. And this fact leads us to conclude about the nature of language: language is the creation of meanings and expressions to be used pragmatically by speakers thus acting in the world7.

The most direct consequence of this is that language is not expression with meaning as it is usually said, but meaning with expression. In language it is meaning, but not expression, the determining thing. Expression certainly exists but in terms of meaning. Meaning is the purpose, aim or function of language, whereas expression is valid as far as it is an instrument of the

\footnotetext{
6 Coseriu 1985a, pp. 37-38.
}

7 Coseriu 1985a, p. 46. 
purpose, aim or function of language. Expression is the instrument of meaning. Hence that the instrument, that is, the expression, can be any type whatsoever. In this sense you would rather say that language is meaning with expression but not the other way round8.

The most important external function of language is communication. Many semanticists think that there is an intrinsic connection between communication and meaning. In communication you have to distinguish two types:

1. The transmission of something to someone. This type of communication belongs to the settings of the application of language to practical things, that is, language used as an instrument; and

2. Communication with someone. This is the prerequisite or essential condition of any speech act9.

Communication as the transmission of something to someone cannot define meaning because meaning is to be transmitted by means of an act of communication, that is, meaning is prior to the act of communication. In effect, when a speaker intends to communicate something to someone he has already decided what to say, something different from the act of communication. When communication fails - and in fact sometimes does-language and thus meaning is still language and meaning. Meaning and language constitute conditions for communication to be.

On the contrary, communication with someone is essential to language, thus making language a particular language. In this sense language is different from poetry, that is, a particular language is not absolute but contingent, always intended to someone, even as a primary linguistic creation. Meanings and signs are not created for their own sake (as art and poetry are). Meaning and signs are created for others, that is, they are created in a particular language, aiming at a particular speaker in a particular circumstance. This means that language and meaning are historical, that is, made in a speech community and thus in history. Meanings thus exist before a speaker contacts with another one, just because they have something in common10. As a consequence communication cannot define meaning. Meaning is the internal determination of language so that language is defined with meaning 11 .

Communication as the transmission of something is important in language use, but meaning is not only important to language but also essential12. Meaning is indispensable for language to be since language exists as the creation of meanings. The fundamental principle in communication is that communication exists insofar as the content in the source coincides with the content in the receiver. The failure in communication does not alter the interpretation due to the speech act.

8 Coseriu,1985a, p. 38.

9 Coseriu 1988, pp. 77-78.

10 Referring to Heidegger, Coseriu says "communication exists because both speaker and listener have already something in common manifesting in speaking to one another" (Coseriu, 1985a, p. 31; my translation).

11 Cf. Coseriu $1985^{\mathrm{a}}$, p. 38.

12 Cf. Coseriu 1985a, p. 39.

\subsection{Free Intentional Creations of Meanings}

Meaning is the arraignment of human experience. The arrangement of things by language does no involve delimitations, divisions, indications or landmarks prior to language. That is, linguistic arraignment of things does not follow previous experience. This means that the linguistic arraignment of human experience is not necessary but contingent and thus intentional. The arraignment of human experience is the one you have in the different languages but there could be different ones. In fact, the many languages in the world make different arraignments or delimitations of facts of experience. In this sense languages cannot be conceived of as different nomenclatures, materially diverse for things already given. They constitute different webs of meanings systematizing the world of experience in a different way in every case. This means that language is not proof or verification of things in the world, but imposition of limits or boundaries on the things experienced 13 .

A language is an arraignment of facts of experience so that speakers of a particular language believe that their ideas about the world are universal. Consider the words by Benjamin L. Whorf (1897-1941) describing a language without the concepts of space and time:

The Hopi language [...] contains no words, grammatical forms, constructions or expressions that refer directly to what we call "time", or to past, present, or future, or to enduring or lasting, or to motion as kinematic rather than dynamic (i.e. as a continuous translation in space and time rather than as an exhibition of dynamic effort in a certain process), or that even refer to space in such a way as to exclude that element of extension or existence that we call "time", and so by implication leave a residue that could be referred to as "time". Hence, the Hopi language contains no reference to "time", either explicit or implicit14.

In fact the Hopi language, in a similar way to English or Spanish, imposes certain views on its speakers in accordance with they think and act in the way they think things are.

This does not mean that linguistic arraignments or systematizations cannot follow natural physically objective limits or boundaries in the things in the world. In language there is no objectively compulsory reason to follow those limits. In meaning there are some objective criteria but meaning does not necessarily relate to objectively delimited boundaries 15. There is no imperative reason in English to separate the facts of experience,

flesh and meat; morrow, morning, noon, afternoon, evening or to apply differently,

young and new; or produce and yield;

13 Coseriu 1985a, p. 39.

14 Whorf 1956, pp. 57-58.

15 Coseriu 1985a, pp. 39-40. 
or to distinguish between stairs/staircase and ladder; and so on.

Properly and primarily, meaning does not arraign external things but internal. Facts of experience are conceived of as something already known, thus constituting contents of conscience. To this respect Aristotle says that words are

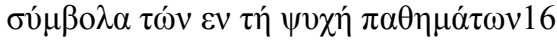

[words are] symbols of things experienced in the soul (=the mind).

External stimuli can be very helpful, say the percept of a tree, but the word 'tree' does not refer to that percept, but to tree as something intuited by speakers as content of conscience.

In this sense in language there is no distinction between internal and external objects. Objects of imagination are conceived of in exactly the same way as the objects perceived through sensitive perception. Siren 17, centaur18, has the same objective base as degree, measure, meter, and the same as donkey, cat or dog. In this sense, the existence of names is not a proof of the existence of the things or objects they denote. On the other hand, meaning in its primary absolute nomination is to a certain extent subjective: it is the objectification of a subjective content of conscience. The complete objectivity of meaning cannot be reached but through the simultaneous inter-subjectivity of all acts of naming, that is, through the essential and original historicity of language 19. The meaning of 'tree' is only objective insofar as it is the content of conscience of the speakers of a speech community, that is, insofar as it is common and historical, thus belonging to a language 20 .

\subsection{Universality of Human Experience: Meaning vs. Designation}

Meaning as such does not relate to things as entities, but to the being of things, that is to the universal human experience. In other words: language does not deal with individual experience but the infinite possibility of experience 21 . For example, the word "tree' means "being a tree", that is, it means the infinite possibility of "being a tree". In this way the word 'tree' can be applied to existing trees as well as to trees no longer existing or trees to exist in future, imaginary trees or even non-existing trees. The word 'tree' is to be applied only to an internal experience, since the real experience does not admit that application. Hence that designation of things in language is something secondary and conditioned: designation is merely a possibility that can only be created through meaning. In this sense meaning can be defined as the

16 Apud Coseriu 1985a, p. 40.

17 A woman-like creature, whose singing attracted sailors and caused the wreck of their ships.

18 One of a race of animals said to be half a man and half a horse.

19 Coseriu 1985a, p. 40

20 Apud Coseriu 1985a, p. 40.

21 Coseriu 1985a, p. 41 possibility or virtuosity of designation 22 .

Words can certainly designate individual things as well. But this designation is only possible through universal signification and only by means of individualization through an act of determination. In the same way personal pronouns and demonstratives are universal in the meaning they convey, but only through the determination made by the situation of speaking can they designate individual entities. Proper names, on the other hand, are secondary elements in language, since they need an operation of historical individualization, not simply an occasional individualization.

Designation and meaning are thus two linguistic functions completely different from each other. Meaning is formal; designation is objective. Linguistic content is made up of both functions23. Designation on the other hand can be real or imaginary. There are many things called tree to be referred to as tree, but a siren has never existed and has been referred to as a siren.

\section{Corollary}

\subsection{Language Created the World}

The three aspects characteristic of meaning analysed here (the fact that language primarily means so that similar expressions do not involve similar meanings, § 2.1.; the arrangement of human experience, $\S 2.2$; and the infinite possibility of experience, $\S 2.3$.), make possible for language to be overcome and, as a consequence, to operate even on things in the world in a particular and peculiar way, the one created and structured by language. The delimitation of things by language is no obstacle to manipulate the world. As a matter of fact, language is the access to things. Language in so far as it is meaning makes possible speaking assertively thus dealing with things and making possible science. Science starts with the thing apprehended and delimited by means of language. Science does not deal with anything linguistic but extra-linguistic24.

Meaning is just the possibility of designation. Language can be made into a system of designation. Science consists in a system in which designation and meaning coincide. Nouns in science are previously determined for individual designations or classes objectively delimited.

In this sense, we can say that language created the world. But this statement must be interpreted as the only world existing for speakers, even if they are scientists and want to study reality. Real things exist just as they are structured, delimited and created with language, both in the content they are designated with and the part of reality they designate. A chair, for example, is a real object insofar as it has been conceived of, delimited and created in the content and designation of it, fabricated with language. And the same can be said of a rat in Spanish, una rata, in the feminine gender,

22 Coseriu $1985^{\text {a }}$, p. 41.

23 Coseriu 1985a, p. 41.

24 Cf. Coseriu 1985a, pp. 41-42. 
although as a matter of fact there are males and females in the species. And the same can be said of freedom: who can ever say that they have seen or touched freedom? However you can say that they lived or experienced freedom.

\subsection{Language is the Basis for Science to Be}

The delimitation of things by means of language is no obstacle to manage things. As a matter of fact, language is the access to real things 25 . In effect, language makes possible for you to speak assertively, something having to do with real things and the truth of things, thus constituting the starting point of science. Science is possible only with things previously apprehended and delimited by means of language. But science however has no connection with meanings but things, although by means of language, that is, by means of designation. Science does not deal with meanings but designation 26 and even this designation is given by means of meanings.

The arrangement of things by means of language is not performed in the world of things, but at the level of human apprehension, that is, in connection with the world of things. Language prepares things for science thus making the primary delimitation of things necessary for things to be 27 .

\subsection{Language is the Possibility of Knowledge}

The arraignment of the world by means of language is not a limitation but the possibility of knowledge of this world: every language is the base and the instrument of objective knowledge. The arraignment of things with language constitutes a world of meanings, not affecting the things referred to, but making them appear as arraigned. This arraignment is not executed in the outer world of things but at the level of human apprehension; that is, it is executed in the sphere of the human conscience although in connection with the world of things. Language prepares things for science. Language gives things a preliminary and necessary delimitation. But this preliminary and necessary delimitation is overcome by science. This overcoming is made through language in models offered by particular languages 28 .

As a matter of fact science starts with an arbitrary linguistic arraignment of the world and makes it into an objectively motivated arraignment, thus constituting a possibility of language: in principle a linguistic arraignment can be any whatever. Amongst the many possibilities of language, one of them is language objectively motivated, that is, language in as much as it is used only for establishing and accepting delimitations relating to a real classification of things in the world and to limits objectively motivated and evaluated. In this sense scientific language, a technical language, as one of the many possibilities of language, is executed only partially

25 Coseriu 1985a, p. 41

26 cf. the difference between designation, meaning and sense, Coseriu $1985 \mathrm{a}$, p. 53 , footnote 4; Coseriu 1985a, p. 247.

27 Cf. Coseriu 1985a, p. 42.

28 Coseriu 1985a, p. 42. in historical languages, namely, in a nomenclature or terminology29. For example, in English, when you speak of the ear in medical terms, you have a whole range of words to be used insofar as they refer to things objectively motivated, that is, defined scientifically. You have cochlea, Eustachian tube, stirrup, anvil, semi-circular canals, auditory nerve, hammer, auricle, thus constituting a nomenclature. In a nomenclature the language is executed only partially since the words identify with things denoted, that is, the content and designation in words of a nomenclature are the same thing. There is no meaning or systematization on the part of language in them.

The distinction between existent and non-existent depends on language. The question about the existence of things is only possible in any case thanks to meaning. In connection with meaning you can ask whether this or that meaning relates to the essence denoted, or if this or that can be verified in the real world. The identification thus of meaning and real objects is a mistake. Language does not deal with existence or non-existence. Language merely gives the possibility of asking for the existence and thus of arraigning a conventional technical language with only names for things existing30. For example, formerly feathers of hens, cocks and turkeys were used as instruments for writing. In Spanish the word for feather was used as the word denoting both the instrument for writing and the feathers of birds. Later on an artificial instrument for writing was invented and the word 'pluma' was definitely assigned to it. From that moment on the instrument for writing is an independent existing thing. That is, language with the word 'pluma' made possible the existence of the new instrument.

Since meaning is the possibility of designation, a language can be made into a system of designation, thus made into a technical language. In science meaning and designation coincide 31 . In language meanings primarily designate classes of things, not individual things. They can as well designate individual things but only through the operation of determination with the help of contexts and situations. Contrary to science linguistic categories are inclusive32. For example,

flower, cat, roof, house,

designate classes of things. They can be applied to individual things only theoretically thus denoting only the essence of those classes of things. In themselves these classes do not designate things. The designation of things is possible through the use of certain means of expression existing in some particular languages, namely, determiners. For example, the following expressions

this flower; the cat on the roof; the house next doors,

\footnotetext{
29 Coseriu 1985a, p. 43; Coseriu 1981, p. 96

30 Coseriu 1985a, p. 43

31 Coseriu 1985a, 43; Coseriu 1981, p. 98.

32 Coseriu 1985a, p. 44.
} 
designate real things. In languages with no determiners determination is made by means of contexts and situations. At the same time linguistic classes are usually inclusive, that is, a word can designate a class of semantic objects and a lower or upper class of objects. For example, if I say,

I'll stay in that hotel for three more days

you mean both three days and three nights, that is, day means the class "day" and its opposite or lower class "night". In linguistic oppositions a term, say A, can mean A and non-A. In a technical language, this is not possible. In this sense a scientific language is a special use of language 33. But this does not mean that language is a phase in science. Science uses language but studies and analyses things designated as such objects designated. In this sense statements in science are statements about real things. On the contrary: language does not give any information about real things: it merely informs about the way to represent them 34 . Linguistic arraignments of real things constitute knowledge, but merely the first manifestation of knowledge, a distinguishing kind of knowledge in which something is apprehended as identical with itself (that is, uniform) and different from the others 35. Meaning is $\lambda$ ó ${ }^{\circ} \varsigma$ in the etymological sense of this word, that is, meaning is selection of a mode of being and thus representation of being but not a statement about things 36 .

In this sense language is not true or false, as Aristotle pointed out. Language does not involve analysis and re-composition of the being of things. Language simply stands for (that is, represents) the being of things apprehended. Words are intuitive delimitations of things not motivated definitions of things. Even compound words, which relate to definitions of things, that is, to statements about things, cannot be considered statements about things 37 . In this sense a walnut is not a foreign nut $(<\mathrm{OE}$ wealh $=$ foreign + nut $)$, but a kind of hard fruit; or downtown does not refer to the lower part of the town, but to the monumental or old town centre, the citadel; or to say goodbye does not refer to the act of saying the thing stated.

Meaning is intentional. This means that language makes an immediate verification of things, but the linguistic expression is understood beyond the immediate. Language is an activity motivated with particular purposes, not conditioned by natural causes. As an activity language creates meanings, that is, language is creative activity, enérgeia 38

\section{Types of Meaning}

In the technique of speaking linguistic meaning is manifest in many ways: in a language the following kinds of meaning

\footnotetext{
33 Coseriu 1985a, p. 45.

34 Cf. Coseriu 1985a, p. 45.

35 Coseriu 1985a, p. 45; Coseriu 1985a, pp. 26-27.

36 Coseriu 1985a, p. 45.

37 Coseriu 1985a, pp. 45.

38 Coseriu $1985^{\mathrm{a}}$, pp. $45-46$.
}

can be distinguished:

\subsection{Lexical Meaning}

It is the meaning relating to the essence of linguistic apprehension of the world. It is the answer to the question, what do you perceive? What do you apprehend? What's this? It consists in the arraignment or primary systematization of experience by means of words in a language. It is the peculiar and particular configuration of facts of experience made in every language. The primary systematization of experience by means of words39 of a language may have different forms and be given in different linguistic categories. For example, the fact of experience making you say that «you feel cosy and thus comfortable», in English is systematized with two words, warm and warmth; similarly the pairs young and youth mean the state of affairs having to do with the application of the concept "age" to different semantic objects thus giving different states of affairs; deep and depth deal with states of affairs having to do with the level of the ground extending down from the surface; and high and height denote a state of affairs having to do with the position of things in connection with the perceiver of those things. In all these pairs, the lexical meaning denoted is the same: they represent a particular criterion introduced in the language in order to conceive of the objects in the world. These criteria do not exist in themselves: they represent useful concepts used by the language in order to systematize the facts of experience. In this way you can describe things, and say

The wall is high; the mountain is high.

But at the same time you can say

the height of the wall; the height of the mountain.

The state of affairs described in both cases is the same. The lexical meaning of high is the same as the one of height. Because of this, the primary systematization of experience by means of words 40 of a language can differ from the systematization made in another one. Lexical meaning is proper and peculiar of every language. Every language has its peculiar and particular configuration of meaning, characterizing itself because of that configuration. Needless to say that every configuration of meaning and every meaning in a language is arbitrary, that is, end-directed and historically motivated41. The description of the state of affairs denoted with the English word child and the Spanish word niño is different, since the English word includes both males and females with no reference to sex. The Spanish word stresses a direct reference to masculine semantic objects but includes at the same time non-masculine objects.

Meaning is different from real things. The arrangement of real things is different from the words used to evoke it.

\footnotetext{
39 Coseriu 1981, p. 88

40 Coseriu 1981, p. 88

41 Cf. Coseriu 1985a, pp. 37-38; Coseriu 1988, 24, footnote ${ }^{\circ} 38$.
} 
Meaning is something independent, traditional, autonomous, structured in internal relationships of dependence within its parts and components.

For example, the different way as Spanish and English apprehend the fact of experience you call wall can be represented in the following diagram:

\begin{tabular}{|c|c|c|c|}
\hline \multicolumn{3}{|c|}{ /SEPARATING/ } & /SURROUNDING/ \\
\hline \multirow{6}{*}{ 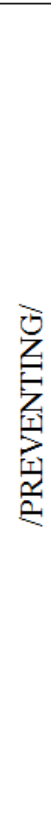 } & \multirow[t]{2}{*}{$\begin{array}{l}\text { W } \\
\text { E } \\
\text { A } \\
\text { K }\end{array}$} & \multirow[t]{2}{*}{ Tabique } & Valla \\
\hline & & & Cerca \\
\hline & \multirow[t]{4}{*}{$\begin{array}{c}\mathrm{S} \\
\mathrm{T} \\
\mathrm{R} \\
\mathrm{O} \\
\mathrm{N} \\
\mathrm{G}\end{array}$} & \multirow[t]{2}{*}{ Muro } & Tapia \\
\hline & & & Muralla \\
\hline & & Pared & Pared \\
\hline & & \multicolumn{2}{|r|}{ Wall } \\
\hline
\end{tabular}

Figure $n^{\circ}$ 1. Representation of the fact of experience wall

Both in English and Spanish the features (or semes) /preventing/+ /separating/+/surrounding/ $\}$ define the fact of experience represented with the words in the diagram thus constituting lexemes, words playing the lexical function42. In English there is only one word, 'wall'; in Spanish, seven, with the following distribution: three of them, 'tabique', 'muro' and 'pared', are to be defined with the semes $\{/$ separating/+/preventing/ $\}$; and five, 'valla', 'cerca', 'tapia', 'muralla', and 'pared' with the semes $\{1 /$ preventing/+ /surrounding/ $\}$; but only one ('pared') with $\{/$ preventing/+/separating/ $+/$ surrounding/ $\}$. At the same time four lexemes, 'tabique', 'valla,', 'cerca' and 'pared) can be /weak/, but four, 'muro', 'tapia', 'muralla', 'pared', can be /strong/. The conclusion to be drawn is that 'pared' is the most genuine of all, thus representing the meaning in all of them or the archilexeme. In English there is only one word, 'wall' corresponding to them all.

Words with this kind of meaning are called lexematic words, also called full content words. Lexematic words are constituted basically with three classes: nouns, adjectives and verbs.

42 In the structural study of meaning, when you want to designate a feature, that is, a seme, the same as with other levels of structural linguistic study, you use slashes (/) to mean that you deal with a feature in a particular meaning or a lexeme. In semantics and the study of meaning in general the smallest meaningful functional and independent unit is called a lexeme. A lexeme is made up of several features or semes. For example, the lexeme young is made up of the set of features (or semes): young $=\{/$ for human beings $/+/ B E$ of age: short/ $\}$, where /human beings/, /BE of age/and/short age/are features of the lexeme young. On the other hand young can be considered a feature in another lexeme. For example, infantile is to be analysed as the set, infantile $=\{/+$ HUMAN $/+$ /young $/+/$ not speaking yet $/\}$.

\subsection{Category Meaning}

It is the kind of meaning relating to the mode the linguistic apprehension of things. It is the answer to the question, how do you apprehend the world? It is the meaning of grammatical categories (nouns, verbs, adjectives, adverbs). In this way warm differs from warmth, although they have the same lexical meaning. High and height; young and youth, new/old and grow old mean differently, although they have the same lexical meaning. They convey different shades of meaning having to do with the way lexical meaning is conveyed. The analysis of words concerning the way they convey their category meaning, is the analysis of the grammatical categories themselves, namely, nouns, adjectives, verbs and adverbs. Adjectives apply the state of affairs they convey to the state of affairs denoted with their headword. Nouns denote something as constituting semantic objects. Verbs refer the meaning they convey to states of affairs with capability of establishing different relationships of signification with the other elements in the same state of affairs. And adverbs modify the relationship of signification in the verb or adjective. In this sense,

The young members of the family

differs from,

The young in the family

In the first case you refer to members of the family who are young, but in the second you refer to persons in the family who are defined as young within the family in contrast to the grown-ups, that is, the children. In the first case you have members referred to as young; in the second one, you have members defined as young thus constituting a different category.

Words with only category meaning are called categorematic words (I, you, he, she, they, this, that, here, now, so).

\subsection{Instrumental Meaning}

It is the kind of meaning relating to the content conveyed by morphemes, either if they are independent or not. For example, the -s morpheme in, some tables, means plurality, but in, Peter's house, it plays the function of determining the meaning in the head-word; in, he comes, it relates to the third person, singular, simple present. In the same way the determiner, the, in, the man, orientates a category of objects to a particular object so that the expression does not mean "the category of man", but "a particular member of the category of man". Similarly, some, in the expression, some men, orientates the category to indefinite members of the class man.

Words with instrumental meaning are called morphemic words. In instrumental meaning you can find,

a) the determiners (a/an, another, every, each, either, neither, one, this/these, that/those, both, few, many, several, two, little, much, my, our, your, her, his, its, John's, the, no, all, some, any);

b) auxiliaries (do/does/did, am/are/is/was/were, 
have/has/had, can/could, may/might, will/would, shall/should, ought to, must, dare, need);

c) prepositions (by, at, under, above, into, within, without, throughout, because of, in view of, according to, by means of, etc.);

d) conjunctions (and, or, but, nor, for, so, yet, both, either, neither, not only... but);

e) clause connectors (therefore, indeed);

f) subordinators (because, when, where, if, since, as, etc.);

g) relatives (who, which, when, where, why, how, that); or

h) quantifiers (many, a few, several, plenty of, a lot of, lots of, a great deal of, a large amount of, a small quantity of);

i) interrogatives (where, when, why, how; who which, what).

j) intensifiers (very, quite, awfully, far, distinctly, quite, too, fairly, rather, really, slightly, clearly, deeply, faintly, greatly, highly, largely, lightly, mildly, strongly);

k) anticipative (there, it).

Morphemic words are also called function words 43.

\subsection{Syntactic or Structural Meaning}

It is the meaning conveyed by lexematic and categorematic words with morphemes within a sentence. It is the contribution of all elements making up a sentence and specifying a particular aspect of that sentence. In this sense expressions like

The English defeated the Picts, and

The Picts were defeated by the English.

have the same designation, lexical and category meaning but they are to be dealt with different syntactic meaning. They refer to different points of view in the conception of things. The first example is to be analysed as \{determined (plural Agent: English) + verb: past: active + plural (Patient: Pict) $\}$; the second one as \{determined (plural Patient: Pict) + past: passive (defeat) + plural (Agent: English)\}. That is, the different meaning conveyed has to do with the combination of words, that is, syntax.

In this sense the meaning conveyed in the combination of linguistic elements belongs, not to words, but to the very combination of words. It belongs to the system of the language. Functions such as singular/plural, present/past/future, perfective/non-perfective, personal/non-personal, comparison/non-comparison, phrase/clause, subject/object/adjunct, constitute syntactic categories, types of meaning belonging to syntactic or structural meaning.

\subsection{Ontic Meaning}

It relates to the value of expressions in terms of the existence or non-existence of the content conveyed, or the truth or non-truth of the expression and the things referred to. Ontic meaning belongs only to sentences, for example,

43 Cf. Christophersen and Sanved, 1971, pp. 66-101. functions such as affirmative, negative, interrogative, imperative, exclamations, etc. The expressions

The man is tall

The man is not tall

Is the man tall?

What a tall man! How tall the man is!

have the same designation, lexical meaning, category meaning, instrumental meaning, syntactic meaning but different ontic meanings. In every case it is said something in connection with the existence or truth of the elements implicit in them. In the first example the existence and truth of the content conveyed are stated; in the second, the existence and truth of the content conveyed are denied; in the third the existence of the object man is stated but both the existence and truth of the content in the expression are brought into question; and in the last one the attitude of the speaker in connection with the content expressed in it is denoted.

The distinction between structural and ontic meaning, both affecting the sentence, is similar, to a certain extent, to the distinction between lexical meaning and category meaning in words: the structural meaning of a sentence relates to the essence of the thing apprehended (what does it mean?), whereas ontic meaning relates to the existential mode of the thing apprehended (how does it mean what it does?). All sentences in the examples have the same structural meaning (they all have the same syntactic relationships) but have different ontic meanings since the same state of affairs is given different existential values 44 .

Lexical meaning exclusively relates to vocabulary, that is, the lexis of a language, and it is the exclusive study of lexicology. The other types of meaning relate to grammar. Coseriu represents this in the following diagram 45.

\begin{tabular}{||l|c||}
\hline Lexical meaning & Lexicon (lexicology) \\
\cline { 1 - 1 } Category meaning & \multirow{2}{*}{ Grammar } \\
\cline { 1 - 1 } Instrumental meaning & \\
\cline { 1 - 1 } Structural meaning & \\
\hline Ontic meaning & \\
\hline
\end{tabular}

Figure $n^{o} 2 .^{46}$ : Types of meaning.

The nature of the different types of meaning can be seen in the different relationships of meaning they establish. Because of these they are to be assigned to different branches of language study. They all belong to grammar except for the lexical meaning.

44 Coseriu 1985a, pp. 248-249; Coseriu 1981, p. 89; Coseriu 1987, pp. 136, 140 and 208 .

45 Coseriu 1987, p. 140

46 Coseriu, 1987, ibidem. 


\section{Conclusion}

Five characteristics define meaning: a) meaning is internal, that is, it is based and related to the human conscience; $b$ ) meaning structures things in the world thus imposing criteria on them; c) meaning depends on the particular speech community (=particular language) it is created by; d) linguistic categories are inclusive, they denote both the class they refer to and upper and lower classes of the one referred to; and e) meaning is intentional, the manifestation of human intelligence and freedom. On the other hand, designation is another function of linguistic content, to be created only by means of meaning.

\section{References}

[1] Aarts, Jan M. G \& Joseph P. Calbert, Metaphor and Non-Metaphor: the Semantics of Adjective Noun Combinations, Tübingen: Max Niemeyer Verlag, 1979.

[2] Bloomfield, Leonard, Language, London: Allen \& Unwin, 1976 (1933).

[3] Chomsky, Noam, Aspects of the Theory of Syntax, The MIT Press, 1965.

[4] Christophersen, Paul \& Arthur O. Sanved, Advanced English Grammar, Macmillan, 1971.

[5] Collins-Cobuild English Language Dictionary, Collins, 1997.

[6] Coseriu, Eugenio, Sistema, norma y habla, Montevideo, 1952.

[7] Coseriu, Eugenio, Tradición y novedad en la ciencia del lenguaje: estudios de historia de la lingüística, Madrid: Gredos, 1977 (1971).

[8] Coseriu, E., Principios de semántica estructural, Madrid: Gredos, 1981 (1977).

[9] Coseriu, E., Teoría del lenguaje y lingüística general: cinco estudios, Madrid: Gredos, (1982) [1962].

[10] Coseriu, E., El hombre y su lenguaje, Madrid: Gredos, 1985a [1977].

[11] Coseriu, Eugenio, "Linguistic Competence: What is it Really?" The Modern Language Review, vol, XXV-XXXV, 1985b.

[12] Coseriu, E., Introducción a la lingüística, Madrid: Gredos, $1986 \mathrm{a}$.

[13] Coseriu, E., Lecciones de lingüística general, Madrid: Gredos, 1986b.

[14] Coseriu, E., Gramática, semántica, universales. Estudios de gramática funcional, Madrid: Gredos, 1987 [1978].

[15] Coseriu, E., Sincronía, diacronía e historia: el problema del cambio lingüístico, Madrid: Gredos, 1988 (1956).

[16] Coseriu, Eugenio, “Semántica estructural y semántica cognitiva”, Homenaje al Profesor Francisco Marsá/Jornadas de Filología, Colecció homenatges, Universidad de Barcelona, 1990: 239-282.

[17] Coseriu, E., Competencia lingüística: elementos de la teoría del hablar, Madrid: Gredos, 1992 [1988].

[18] Coseriu, E. y Ó. Loureda: Lenguaje y discurso, Pamplona,
Eunsa, 2006.

[19] Coseriu, E., Lingüística del texto. Introducción a la hermenéutica del sentido, Arco/Libros, 2007 [1973].

[20] Dik, Simon C., Functional Grammar, Amsterdam: North-Holland, 1978, Spanish translation, 1981.

[21] Geckeler, Horst, Semántica estructural y teoría del campo léxico, Madrid: Gredos, 1976 (1971).

[22] Geckeler, Horst, "Structural Semantics". H J Eikmeyer \& H Reiser, eds. Words, Worlds, and Contexts: New Approaches in World Semantics, Berlin \& New York: Walter de Gruyter, 1981, pp. 381-413.

[23] Longman Dictionary of Contemporary English, Longman.

[24] Longman Language Activator, Longman, 1988.

[25] Lyons, John, Semántica, Barcelona: Teide, 1980 (1977).

[26] Martínez del Castillo, Jesús, An Open Dimension of Meaning: A Semantic Study of Adjectives and Their Combinations, Universidad de Almería, 1997.

[27] Martínez del Castillo, Jesús, La intelección, el significado, los adjetivos, Universidad de Almería, 1999.

[28] Martínez del Castillo, Jesús, Significado y conocimiento: la significación de los adjetivos subjetivos, Granada Lingvistica,

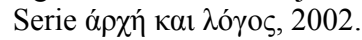

[29] Martínez del Castillo, Jesús, La lingüística del decir. El logos semántico y el logos apofántico, Granada: Granada Lingvistica,

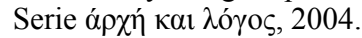

[30] Martínez del Castillo, Jesús, «Hablar, decir y conocer: el acto lingüístico», Oralia, 11, 2008, pp. 375-397.

[31] Martínez del Castillo, Jesús: «El logos semántico y el logos apofántico», Enérgeia I, Online-Zeitschrift für Sprachwissenchaft, Sprachphilosophie und Sprachwissenschaftsgeschichte, 2009, pp. 50-80.

[32] Martínez del Castillo, Jesús, ed., Eugenio Coseriu (1921-2002) en los comienzos del siglo XXI, 2 vols. in Analecta Malacitana, Anejos/86, 2012.

[33] Martínez del Castillo, Jesús, English Semantics and Lexicology, Universidad de Almería, 2013.

[34] Martínez del Castillo, Modes of Thinking, Language and Liinguistics, in Analecta Malacitana, 2013.

[35] Martínez del Castillo, Meaning and Language. International Journal of Language and Linguistics. Special Issue: Linguistics of Saying. Vol. 3, No. 6-1, 2015, pp. 50-58.

[36] McArthur, Tom, ed., Longman Lexicon of Contemporary English, Longman, 1981.

[37] McArthur, Tom, ed., The Oxford Companion to the English Language, Oxford, New Your: Oxford University Press, 1992.

[38] Ortega y Gasset, José, ¿Qué es conocimiento?, Alianza Editorial, 1992 [1984].

[39] Ortega y Gasset, José, El hombre y la gente, Alianza Editorial, 2001 (1957).

[40] Ortega y Gasset, José, Meditación de la técnica y otros ensayos de ciencia y filosofía, Alianza Editorial, 2002 (1993).

[41] Ortega y Gasset, José, Obras completas, IX, Taurus, 2009. 
[42] Pottier, Bernard, Lingüística general: teoría y descripción, Madrid: Gredos, 1976 (1974).

[43] Saussure, Ferdinand de, Curso de lingüística general, Buenos Aires: Losada, 1974 (1916).
[44] Whorf, Benjamin Lee, Language, Thought and Reality, Selected Writings of Benjamin Lee Whorf, Lewis Carrol, ed., Cambridge, Massachusetts: Massachusetts Institute of Technology, 1956. 